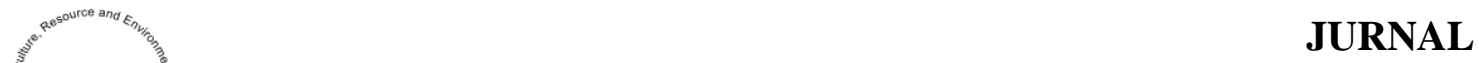 \\ EKONOMI PERTANIAN, SUMBERDAYA DAN LINGKUNGAN (Journal of Agriculture, Resource, and Environmental Economics)
}

\section{ANALISIS EKONOMI DAN KEBIJAKAN SUMBER DAYA ALAM PROVINSI JAWA BARAT}

Economic And Policy Analysis of Natural Resource In West Java Province

Ahmad Heryawan ${ }^{1)}$, Akhmad Fauzi ${ }^{2)}$ dan Aceng Hidayat ${ }^{3)}$

\section{INFO NASKAH :}

Diterima April 2014

Diterima hasil revisi Juni 2014

Terbit Oktober 2014

Keywords :

data envelopment analysis (DEA)

coppock instability index (CII)

farmer's exchange value (NTP)

fisherman's exchange value (NTN)

natural resources

\section{ABSTRACT}

This research analyzed the economic aspect of natural resource in West Java Province, particularly fishery and agriculture. The objectives of the research are: (1) to analyze the diversity of natural-resource-based sectors (particularly fishery and agriculture) in West Java Province during 2001-2012 period, (2) to identify and explain the instability of the natural-resource-based sectors in the long term, and (3) to analyze the connection pattern between the instability of the two sectors and its input and output variables. This research was analyzed using Data Envelopment Analysis (DEA), Coppock Instability Index (CII), and correlation. The result of this research shows that: (1) during the period of $2001-2012$, agriculture sector showed performance towards better direction, while fishery sector tends to fluctuate. The performance of agriculture output could be improved by $8.75 \%$ from the existing condition, while the performance of fishery production could be improved up to 23\%, (2) interaction between instability index and the input and output (labor, NTP and NTN) shows that there are policy dynamics on the input and output in fishery and agriculture sector, (2) in agriculture sector, NTP and production has positive correlation to CII. This means that the higher the NTP and production, the more instable the farmer's prosperity is. This is contrary to fishery sector, where the increase of NTN and production tend to stabilize the community's prosperity

\section{PENDAHULUAN}

Sumber daya alam merupakan tulang punggung ekonomi suatu wilayah yang memberikan kontribusi terhadap PDRB dan juga kesejahteraan masyarakat. Namun demikian, ekonomi berbasis sumber daya alam seperti pertanian dan perikanan banyak ditentukan oleh berbagai macam faktor input dan output serta aspek kebijakan yang akan mempengaruhi kestabilan dan keragaan sektor tersebut. Provinsi Jawa Barat sebagai provinsi yang berbatasan langsung dengan DKI Jakarta merupakan penyangga utama bagi ibukota negara. Jawa Barat merupakan provinsi dengan jumlah penduduk terbesar, yakni sebanyak $\pm 44,91$ juta jiwa (proxy BPS Juli 2012) dan laju pertambahan penduduk 1,66\% (proxy BPS Juli 2013). Nilai strategis Jawa Barat dapat dilihat dari nilai PDRB menempati urutan kedua terbesar setelah DKI Jakarta (BPS, 2011) dengan laju pertumbuhan rata-rata PDRB Jawa Barat antara tahun 2000-2010 adalah $5,11 \%$ (BPS, 2010). Nilai PDRB (berdasarkan harga konstan 2000) pada tahun 2011 sebesar 343,11 triliun rupiah (BPS, 2012). Potensi sumberdaya alam Provinsi Jawa Barat antara lain: (1) sektor industri dan pengolahan $(42,08 \%)$, (2) sektor pertanian, terutama sub sektor tanaman pangan yakni 10,29\%, (3) sektor perikanan budidaya, (4) sumberdaya air dan energi juga

\footnotetext{
${ }^{1}$ Gubernur Provinsi Jawa Barat e-mail : adcgub@gmail.com

${ }^{2}$ Departemen Ekonomi Sumberdaya dan Lingkungan, Institut Pertanian Bogor (e-mail : fauziakhmad@gmail.com)

${ }^{3}$ Departemen Ekonomi Sumberdaya dan Lingkungan, Institut Pertanian Bogor (e-mail : $\underline{\text { a.hidayat@gmail.com) }}$
} 
potensial dikembangkan (Pemprov Jabar, 2010). Beberapa permasalahan pokok dihadapi dalam pengelolaan sumber daya alam adalah, keterbatasan data dan informasi dalam kuantitas maupun kualitasnya. Keterbatasan data dan informasi yang akurat berpengaruh pada kegiatan pengelolaan dan pengendalian sumber daya alam yang belum dapat berjalan dengan baik. Sementara itu, sistem pengelolaan informasi yang transparan juga belum melembaga dengan baik sehingga masyarakat belum mendapat akses terhadap data dan informasi secara memadai. Selanjutnya, permasalahan pokok lainnya adalah kurang efektifnya pengawasan dan pengendalian dalam pengelolaan sumber daya alam yang ada, sehingga menyebabkan kerusakan sumber daya alam. Kondisi ini ditandai dengan maraknya pengambilan terumbu karang dan pemboman ikan, sementara pada sektor pertanian ialah perubahan konversi lahan pertanian menjadi kawasan industri dan pemukiman yang secara kumulatif akan turut serta berkontribusi mengancam ketahanan pangan.

Di sisi lain, potensi sumberdaya alam khususnya di Jawa Barat sangat melimpah. Jawa Barat adalah salah satu lumbung padi utama nasional, dengan $26,48 \%$ total luas wilayah Jawa Barat atau 942.974 hektar dialokasikan untuk areal persawahan. Tidak dipungkiri lagi, Jawa Barat merupakan 'rumah produksi' bagi ekonomi Indonesia. Hasil pertanian Provinsi Jawa Barat menyumbangkan kurang lebih $17 \%$ terhadap total produksi padi Indonesia. Selain produksinya yang tinggi, padi di Jawa Barat memiliki produktivitas hampir 6 ton/hektar di atas rata-rata produktivitas padi nasional sebesar 5,2 ton/hektar. Jumlah rumah tangga usaha pertanian di Jawa Barat tahun 2013 sebanyak 3.057.424 rumah tangga (Sensus Pertanian, 2013). Artinya bahwa, selain dari sisi produksi pertanian yang melimpah menjadikan Provinsi Jawa Barat sebagai salah satu wilayah lumbung pangan nasional, disamping itu juga banyak rumah tangga di Jawa Barat yang bekerja di sektor ini sebagai mata pencaharian utama.

Jumlah penduduk Jawa Barat yang bekerja di sektor perikanan semenjak tahun 2007 2011 terus mengalami peningkatan. Jumlah nelayan yang menjadikan sektor perikanan sebagai mata pencaharian utama (2007 - 2011) masing-masing sebesar 0,63\%, 0,71\%, 0,75\% dan $0,75 \%$ atau rata-rata mengalami peningkatan sebesar $0,71 \%$ per tahun. Sedangkan jumlah nelayan yang menjadikan sektor perikanan sebagai mata pencaharian sambilan utama (tahun 2007 - 2011) berturut-turut sebesar: $0,18 \%, 0,26 \%, 0,27 \%, 0,17 \%$ dan $0,16 \%$ atau peningkatan jumlah nelayan di sektor ini rata-rata sebesar $0,21 \%$ per tahun. Jumlah nelayan yang menjadikan sektor perikanan sebagai mata pencaharian tambahan (tahun 2007-2011) masing-masing sebesar $0,19 \%, 0,013 \%, 0,012 \%, 0,079 \%$, dan $0,09 \%$ atau rata-rata mengalami peningkatan jumlah nelayan sebesar $0,077 \%$ per tahun.

Bila dilihat dari total produksi perikanan di Jawa Barat juga terus mengalami peningkatan yang signifikan. Menurut data Dinas Perikanan Provinsi Jawa Barat, hasil perikanan tangkap paling besar diperoleh dari perikanan budidaya (tahun 2007-2011) masing-masing sebesar $0,703 \%, 0,701 \%, 0,719 \%, 0,763 \%$ dan $0,783 \%$ atau rata-rata meningkat sebesar $0,734 \%$ per tahun. Sedangkan hasil tangkapan paling besar selanjutnya ialah berasal dari hasil perikanan tambak (tahun 2007-2011) masing-masing sebesar 0,163\%, 0,165\%, 0,197\%, 0,212\%, dan $0,215 \%$ atau rata-rata mengalami peningkatan sebesar $0,014 \%$ per tahun. Pada hasil tangkapan perikanan laut meskipun hasil produksinya tidak sebesar hasil tangkapan perikanan budidaya maupun tambak, namun cukup signifikan dan berkontribusi cukup besar bagi perekonomian berbasis sumberdaya alam di Provinsi Jawa Barat (tahun 2007-2011) masing-masing sebesar $0,018 \%, 0,019 \%, 0,013 \%, 0,010 \%$ dan $0,009 \%$ atau mengalami peningkatan rata-rata sebesar $0,014 \%$ per tahun. Di sisi lain, jumlah armada perikanan laut di Jawa Barat masih bisa dikatakan terbatas. Sebagai contoh, armada laut untuk mengangkut hasil tangkapan masih didominasi dari armada perahu motor tempel, masih sedikit perahu-perahu motor yang kurang dari 5 Gross Ton (GT). Artinya bahwa melimpahnya produksi perikanan laut di Jawa Barat perlu diiringi oleh fasilitas armada yang memadai, mengingat sangat banyak masyarakat nelayan yang menggantungkan hidupnya pada sector perikanan sebagai mata pencaharian utama.

Tantangan kedepan ialah bagaimana mengelola perekonomian yang berbasis sumber daya alam melalui kebijakan secara efektif, sehingga mampu meningkatkan pendapatan petani dan nelayan di Jawa Barat secara berkelanjutan. Hal ini dapat dicapai dengan mengintegrasikan tiga 
aspek: ekologi, ekonomi dan sosial budaya, sehingga dapat menjaga kelestarian lingkungan bagi generasi saat ini dan generasi yang akan datang.

Keterkaitan antara perkembangan ekonomi dan kelimpahan SDA semenjak lama telah menjadi objek kajian penelitian ekonomi. Secara intuitif, kelimpahan SDA yang dimiliki oleh suatu kawasan mampu menjadi faktor pendorong perekonomian sehingga kawasan yang memiliki kelimpahan SDA seharusnya memiliki kinerja ekonomi yang lebih baik ketimbang kawasan tanpa kelimpahan SDA. Sebuah studi yang dipublikasikan oleh Jeffrey Sachs dan Andrew Warner mengungkapkan adanya hubungan negatif antara kelimpahan SDA dengan kinerja ekonomi (Sachs dan Warner, 1997). Studi ini seakan menguatkan tesis yang sebelumnya dikemukakan oleh Richard Auty yang dikenal dengan Resource Curse hypothesis (Auty, 1993). Namun demikian Fauzi (2007) menyatakan bahwa hipotesisi kutukan sumber daya bisa saja bersifat Ad-Hoc. Harus dibedakan antara kelimpahan sumber daya dengan daya saing daerah yang memiliki sumber daya tersebut. Hal ini bisa dilihat bagaimana keragaan sektor yag berbasis sumber daya alam di daerah tersebut dan sejauh mana stabilitas tingkat kesejahteraan dari pelaku yang bergerak di sektor sumber daya alam seperti petani dan nelayan.

Rumusan masalah dalam penelitian ini adalah : (1) Bagaimana keragaan sektor-sektor yang berbasis sumberdaya alam (terutama pada sektor pertanian dan perikanan) di Jawa Barat selama periode 2001 - 2011? (2) Bagaimana ketidakstabilan dari sektor-sektor yang berbasis sumberdaya alam tersebut dalam jangka panjang? (3) Bagaimana pola hubungan antara ketidakstabilan kedua sektor tersebut dengan variabel-variabel input maupun output dari kedua sektor tersebut? Adapun tujuan penelitian yaitu : (1) Menganalisis keragaan sektor-sektor yang berbasis sumberdaya alam (terutama pada sektor pertanian dan perikanan) di Jawa Barat selama periode 2001 - 2011. (2) Mengidentifikasi dan menjelaskan bagaimana ketidakstabilan dari sektor-sektor yang berbasis sumberdaya alam tersebut dalam jangka panjang. (3) Menganalisis pola hubungan antara ketidakstabilan kedua sektor tersebut dengan variabel-variabel input maupun output dari kedua sektor tersebut.

\section{METODE PENELITIAN}

\section{Lokasi dan Waktu Penelitian}

Penelitian ini dilakukan di Provinsi Jawa Barat, dengan satuan wilayah pengamatan terdiri dari 17 kabupaten dan 9 kota. Tahap persiapan data hingga penyusunan laporan dilaksanakan mulai bulan Mei 2013 - Mei 2014.

\section{Metode Analisis}

Studi ini menggunakan pendekatan non parametrik untuk mengukur keragaan pemanfatan sumber daya alam yakni melalui Data Envelopment Analysis (DEA) yang dikembangkan oleh Charnes et al. (1978) dan Coppock Instability Index (CII) yang dikembangkan oleh Coppock (1962). Pada prinsipnya DEA mengitung skor efisiensi dari input dan output yang digunakan dengan membobot setiap input dan output. DEA memungkinkan digunakannya multiple input dan multiple output. Kelebihan DEA antara lain tidak memerlukan asumsi tertentu tentang fungsi input dan output serta tidak memerlukan batasan dalam pembobotan input dan output. Analisis DEA dilakukan untuk menganalisis keragaan bidang pertanian di Jawa Barat selama periode 2001 sampai 2012 dengan input luas panen dan tenaga kerja serta output adalah produksi.

Formulasi DEA secara umum dapat ditulis sebagai berikut:

Dengan kendala

$$
\max _{\theta, z, \lambda} \theta_{1}
$$

$$
\sum_{i=1}^{N} z_{i} y_{i m} \geq \theta_{1} y_{j m}
$$




$$
\begin{gathered}
\sum_{i=1}^{N} z_{i} x_{i n}=\lambda_{j n} x_{j n}, \quad n \in V_{x} \\
\sum_{i=1}^{N} z_{i} x_{i n} \leq x_{j n}, \quad n \in F_{x}
\end{gathered}
$$

Keterangan:

$\mathrm{y} r \mathrm{j}=$ jumlah output sektor pertanian dan sektor perikanan (produksi panen, dalam ton)

$\mathrm{X}_{\mathrm{ij}}=$ jumlah input $\mathrm{i}$ yang digunakan pada sektor pertanian yaitu luas panen (juta hektar) dan tenaga kerja (juta orang) dan sektor perikanan yaitu jumlah armada dan jumlah tenaga kerja (juta orang)

$\mathrm{ur}_{\mathrm{r}}=$ bobot yang diberikan kepada output $\mathrm{r},(\mathrm{r}=1, \ldots, \mathrm{t}$ dan $\mathrm{t}$ adalah jumlah output $)$,

$\mathrm{Vi}=$ bobot yang diberikan kepada input $\mathrm{i},(\mathrm{i}=1, \ldots, \mathrm{m}$ dan $\mathrm{m}$ adalah jumlah input $)$,

$\mathrm{n}=$ tahun

$\mathrm{j} 0=$ efisiensi sector pertanian dan perikanan

Sedangkan formula CII dapat ditulis sebagai berikut:

$$
C I I=|\operatorname{anti} \log \sqrt{\log V}-1 \times 100|
$$

Dimana

$$
\log V=\frac{1}{n-1}\left[\sum\left(\log x_{t+1}-\log x_{t}\right)-\frac{1}{n-1} \sum\left(\log x_{t+1}-\log x_{t}\right)\right]
$$

Keterangan:

$\mathrm{Xt} \quad$ : Areal produktivitas pada tahun ke t (juta Ha)

n-1 : jumlah tahun/periode

Keragaan sumber daya diukur untuk dua sektor sumber daya alam yakni 1) berbasis lahan dan intervensi budidaya oleh manusia, yakni sektor pertanian, dan 2) sektor yang berbasis sumber daya alam liar (wild) yakni perikanan tangkap. Analisis keragaan diukur dengan melihat skor efisiensi DEA atas dasar input yang digunakan dan output yang dihasilkan. Input yang digunakan pada pertanian adalah luas panen dan tenaga kerja, sementara pada perikanan adalah armada penangkapan dan jumlah nelayan.

Untuk analisis CII, ukuran indeks ketidakstabilan adalah nilai tukar petani dan nelayan yang dijadikan proksi bagi ukuran kesejahteraan petani dan nelayan. Pengukuran indeks ketidakstabilan dilakukan pada nilai NTP bulanan selama empat tahun (48 entri data). Hasil CII kemudian dipetakan dalam matrik plot dan korelasinya dengan variabel input dan output.

\section{HASIL DAN PEMBAHASAN}

\section{Hasil Analisis Data Envelopment Analysis (DEA)}

Data Envelopment Analysis (DEA) adalah metode non parametrik yang dapat digunakan untuk mengukur keragaan (peformance) suatu unit analisis. DEA dikenalkan pertama kali pada tahun 1978 oleh Charnes et al (1978). Pada prinsipnya DEA mengitung skor efisiensi dari input dan output yang digunakan dengan membobot setiap input dan output. Analisis DEA didalam penelitian ini digunakan untuk melihat keragaan dari sektor pertanian dan perikanan selama periode 2001 sampai 2012. Input yang digunakan luas panen dan tenaga kerja serta output adalah produksi. 
Tabel 1 Keragaan/efisiensi pada sektor pertanian Jawa Barat periode 2001-2012

\begin{tabular}{ccccc}
\hline Tahun & $\begin{array}{c}\text { Luas Panen } \\
\text { (juta Ha) }\end{array}$ & $\begin{array}{c}\text { Tenaga Kerja } \\
\text { (juta orang) }\end{array}$ & $\begin{array}{c}\text { Produksi } \\
\text { (juta ton) }\end{array}$ & $\begin{array}{c}\text { Skor } \\
\text { Efisiensi }\end{array}$ \\
\hline 2001 & 1,87 & 4,09 & 9,24 & 0,84 \\
2002 & 1,79 & 5,13 & 9,17 & 0,86 \\
2003 & 1,66 & 5,14 & 8,78 & 0,89 \\
2004 & 1,88 & 4,35 & 9,60 & 0,86 \\
2005 & 1,89 & 5,03 & 9,79 & 0,87 \\
2006 & 1,80 & 5,19 & 9,42 & 0,88 \\
2007 & 1,83 & 4,68 & 9,91 & 0,92 \\
2008 & 1,80 & 3,79 & 10,11 & 0,95 \\
2009 & 1,95 & 3,94 & 11,32 & 0,98 \\
2010 & 2,03 & 3,96 & 11,74 & 0,97 \\
2011 & 1,96 & 3,68 & 11,63 & 1,00 \\
2012 & 1,91 & 3,42 & 11,27 & 1,00 \\
\hline
\end{tabular}

Sumber: Hasil analisis DEA data diolah (2013)

Hasil analisis keragaan (performance) untuk sektor pertanian pada Gambar 1 menunjukkan bahwa pada sektor pertanian selama periode 2001 sampai 2012 terdapat kencenderungan ke arah efisiensi. Hal ini mengisyaratkan adanya pemanfaatan input pertanian yang menunjukkan kinerja ke arah lebih baik dari tahun ke tahun. Penurunan efisiensi hanya terjadi pada periode 2004 sebesar 0,89 yang bisa disebabkan karena terjadinya penurunan tenaga kerja sebesar 7.845 .374 orang, namun terjadi peningkatan jumlah produksi sebesar 825.413 ton pada periode tersebut (Tabel 1).

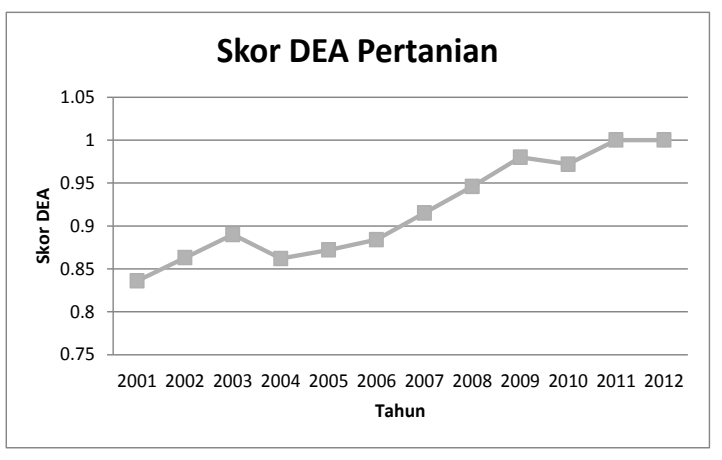

Gambar 1 Keragaan/efisiensi pada sektor pertanian periode $2001-2012$

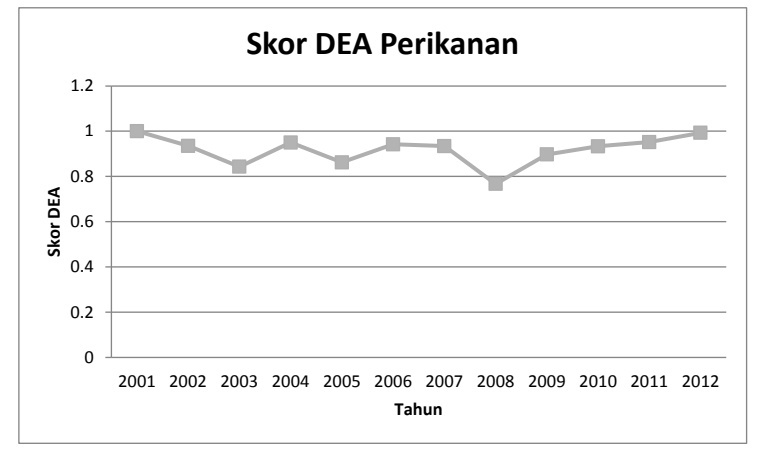

Gambar 2 Keragaan/efisiensi pada sektor perikanan periode $2001-2012$

Di sisi lain, hasil analisis keragaan (performance) untuk sektor perikanan melalui analisis DEA menunjukkan skor efisiensi sektor perikanan cenderung berfluktuasi. Keragaan perikanan cenderung menurun pada periode 2002 sampai 2009, kemudian membaik setelah periode tersebut. Hal ini disebabakan karena pada sektor perikanan produksi tidak hanya ditentukan oleh input yang terkendali namun juga faktor alam seperti cuaca serta fluktuasi yang cukup tajam pada jumlah nelayan yang bekerja (Gambar 2 dan Tabel 2). 
Tabel 2 Tingkat efisiensi pada sektor perikanan periode $2001-2012$

\begin{tabular}{ccccc}
\hline Tahun & $\begin{array}{c}\text { Armada } \\
\text { (unit) }\end{array}$ & $\begin{array}{c}\text { Jumlah Tenaga Kerja } \\
\text { (orang) }\end{array}$ & $\begin{array}{c}\text { Jumlah Produksi } \\
\text { (ton) }\end{array}$ & $\begin{array}{c}\text { Tingkat } \\
\text { Efisiensi }\end{array}$ \\
\hline 2001 & 12.335 & 35.679 & $147.032,04$ & 1,00 \\
2002 & 14.144 & 45.593 & $157.600,50$ & 0,94 \\
2003 & 15.409 & 50.008 & $154.942,38$ & 0,84 \\
2004 & 14.891 & 46.323 & $168.671,96$ & 0,95 \\
2005 & 15.775 & 45.824 & $162.019,00$ & 0,86 \\
2006 & 15.280 & 41.835 & $162.344,48$ & 0,94 \\
2007 & 15.745 & 70.416 & $175.397,10$ & 0,93 \\
2008 & 20.197 & 75.407 & $184.601,60$ & 0,77 \\
2009 & 16.868 & 86.014 & $180.392,14$ & 0,89 \\
2010 & 17.154 & 88.975 & $190.787,81$ & 0,93 \\
2011 & 17.363 & 103.721 & $196.991,09$ & 0,95 \\
\hline
\end{tabular}

Sumber: Hasil analisis DEA data diolah (2013)

\section{Potensi Perbaikan Kinerja}

Jika kita bandingkan rataan DEA dengan rataan riil sektor pertanian, dapat disimpulkan bahwa kinerja output pertanian dapat diperbaiki sebesar $8,75 \%$ dari kondisi eksisting (riil) sedangkan kinerja output perikanan dapat diperbaiki sebesar 9,5\%. Kinerja input tenaga kerja perikanan dapat dikurangi sebesar $35 \%$ dari kondisi eksisting sedangkan kinerja input tenaga kerja sektor pertanian berkurang hingga $27 \%$ dari kondisi eksisting. Kinerja input armada perikanan berkurang hingga $9 \%$ sedangkan input luas panen pertanian berkurang sebesar $8 \%$ seperti terlihat pada Tabel 3 .

Tabel 3 Perbaikan kinerja

\begin{tabular}{|c|c|c|c|}
\hline \multicolumn{4}{|c|}{ Sektor Pertanian } \\
\hline Variabel & Rataan Riil & Rataan DEA & $\begin{array}{c}\text { Perubahan } \\
(\%)\end{array}$ \\
\hline Orientasi Input Luas Panen (juta Ha) & 1,87 & 1,72 & -8 \\
\hline Orientasi Input Tenaga Kerja (juta orang) & 4,37 & 3,20 & -27 \\
\hline Orientasi Output (juta ton) & 10,16 & 11,05 & 8,75 \\
\hline \multicolumn{4}{|c|}{ Sektor Perikanan } \\
\hline Variabel & Rataan Riil & Rataan DEA & $\begin{array}{c}\text { Perubahan } \\
(\%)\end{array}$ \\
\hline Orientasi Input Armada (ribu) & 16,02 & 14,60 & -9 \\
\hline Orientasi Input Tenaga Kerja (juta orang) & 65,70 & 42,30 & -35 \\
\hline Orientasi Output (juta ton) & 174,39 & 190,99 & 9,5 \\
\hline
\end{tabular}

\section{Hasil Analisis Ketidakstabilan (Coppock Instability Index)}

Pengukuran indeks ketidakstabilan Coppock pada studi ini dilakukan dengan mengikuti metode yang sama yang telah diterapkan untuk pertanian oleh Karjogi et al (2009) dan Reddy (2009), serta untuk perikanan oleh Shah (2007), Wasim (2007) dan Fauzi dan Anna (2011).

\section{Sektor Pertanian}

Ketidakstabilan NTP selama periode 2008 sampai 2011 menunjukkan ketidakstabilan NTP yang memiliki indeks Coppock (CII-NTP) jauh lebih kecil jika dibandingkan dengan periode 2010 sampai 2011. Hal ini mengindikasikan bahwa pada periode tersebut cenderung lebih stabil dibandingkan dengan periode 2010 sampai 2011 (Gambar 3). Hasil analisis NTP terhitung mulai periode 2008 terus mengalami peningkatan yang cukup signifikan hingga periode 2011. Namun demikian, kondisi ini diiringi pula dengan indeks ketidakstabilan coppock yang cukup tinggi. Hal ini dikarenakan banyaknya fluktuasi dalam faktor produksi (Gambar 4). 


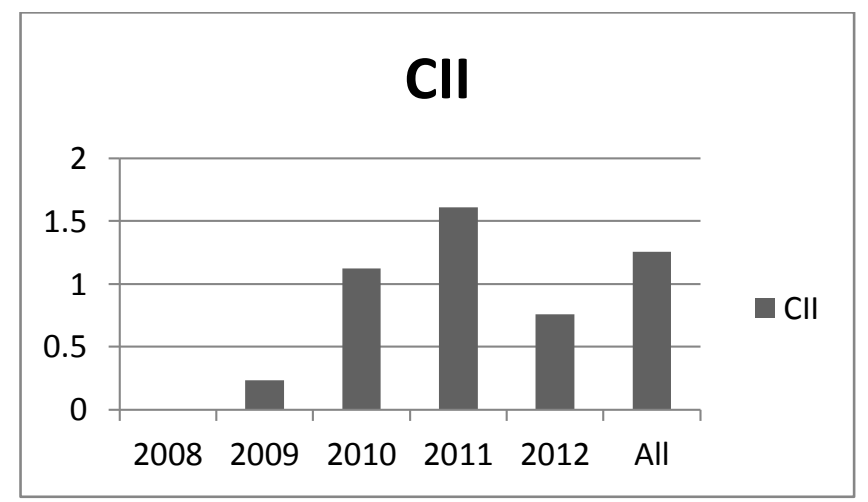

Gambar 3 CII pertanian di Jawa Barat periode 2008-2012

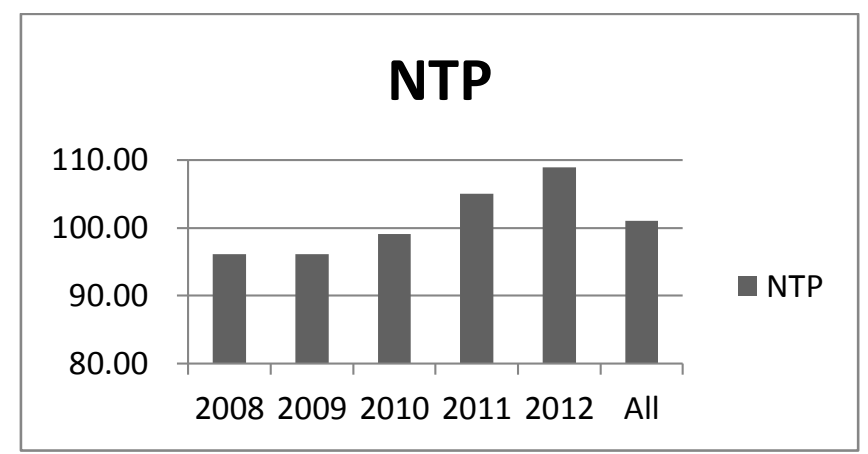

Gambar 4 NTP di Jawa Barat periode 2008-2012

\section{Sektor Perikanan}

Gambar 5 menunjukkan bagaimana ketidakstabilan NTN di Jawa Barat selama periode 2008 sampai 2011. Pada gambar tersebut menunjukkan bahwa selama periode tersebut sistem perekonomian perikanan di Jawa Barat mengalami fluktuasi ketidakstabilan NTN. Puncak kestabilan NTN terjadi pada periode 2008 yang berada pada level indeks 2,26, kemudian merosot tajam pada periode 2011 hingga berada pada level indeks 0,20.

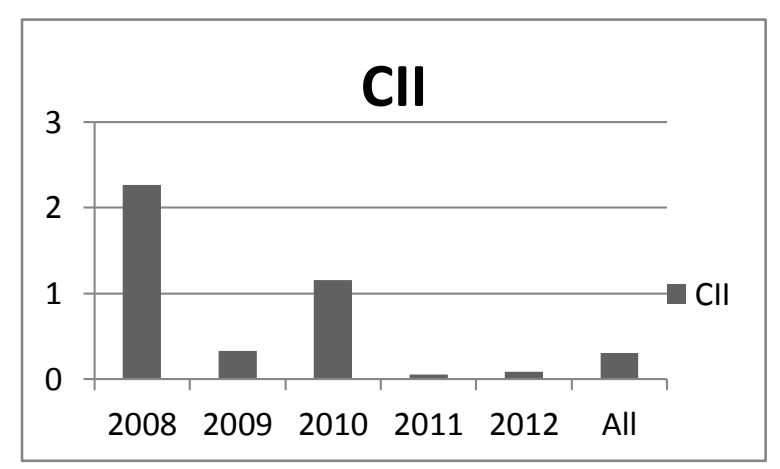

\section{Gambar 5 CII perikanan di Jawa Barat periode 2008-2012}

Temuan ini menarik, karena jika kita telusuri melalui data jumlah nelayan maupun jumlah produksi perikanan di Jawa Barat pada periode 2008 sampai 2011 cenderung meningkat. Dari analisis sebelumnya diperoleh bahwa pada periode 2008 sampai 2011 kenaikan jumlah nelayan dengan indeks coppock (CCI) memiliki korelasi yang negatif, artinya variabel jumlah nelayan tidak merepresentasikan kestabilan sektor perikanan di Jawa Barat. Atau dengan kata lain ada faktor eksternal lainnya yang menyebabkan terjadinya ketidakstabilan NTN di Jawa Barat pada periode tersebut. 


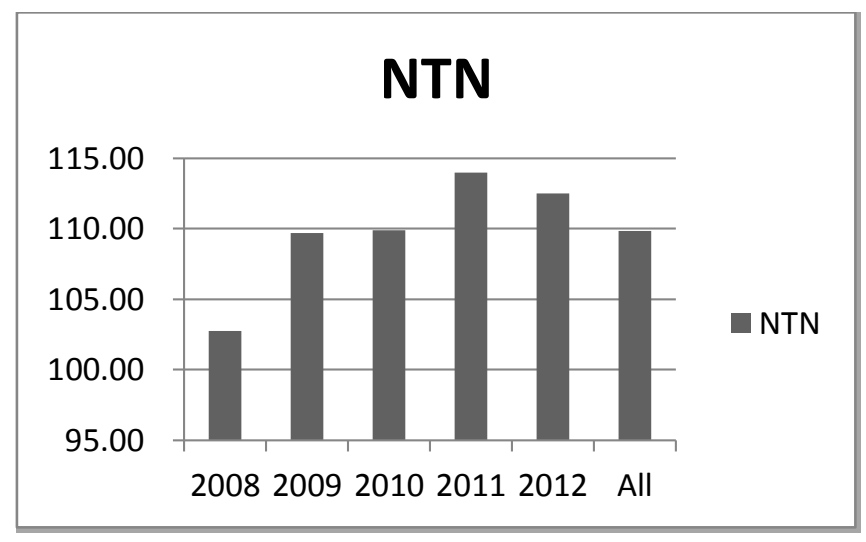

Gambar 6 NTN di Jawa Barat periode 2008-2012

Berbeda dengan analisis ketidakstabilan NTN yang diperoleh sebelumnya yang cukup fluktuatif, pada analisis Nilai Tukar Nelayan (NTN) cenderung mengalami peningkatan yang cukup signifikan selama periode 2008 sampai 2011. Hal ini ditunjukkan pada Gambar 6.

\section{Korelasi CII dan variabel input}

Gambar 7 mengilustrasikan pola hubungan antara jumlah petani dengan indeks ketidakstabilan nilai tukar petani (instability indeks NTP) yang ditunjukkan oleh indeks ketidakstabilan Coppock (CII) selama periode 2008 sampai 2011. Terlihat pada grafik adanya pola U-terbalik selama periode tersebut. Mengindikasikan, kenaikan jumlah petani cenderung meningkatkan ketidakstabilan NTP. Namun tidak demikian pada periode 2011 dimana jumlah petani menurun namun indeks ketidakstabilan NTP tetap tinggi.

Selanjutnya pada Gambar 8 memperlihatkan hubungan antara NTP dengan indeks ketidakstabilan Coppock (CII) selama periode 2008 sampai 2009 cenderung stabil di bawah 97 kemudian pada periode 2010 dan 2011 NTP cenderung meningkat secara eksponensial dengan loncatan yang relatif tinggi. Loncatan yang tinggi ini cenderung meningkatan ketidaksatabilan NTP di masa mendatang karena goncangan (shock) pada komponen input dan output bisa mengarah kepada ketidakstabilan di sistem perikanan.

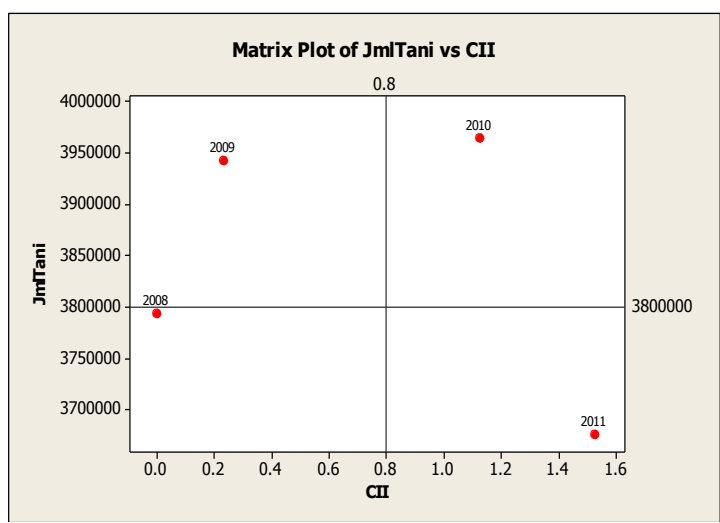

Gambar 7 Pola Hubungan antara Jumlah Petani vs Indeks Ketidakstabilan (CII)

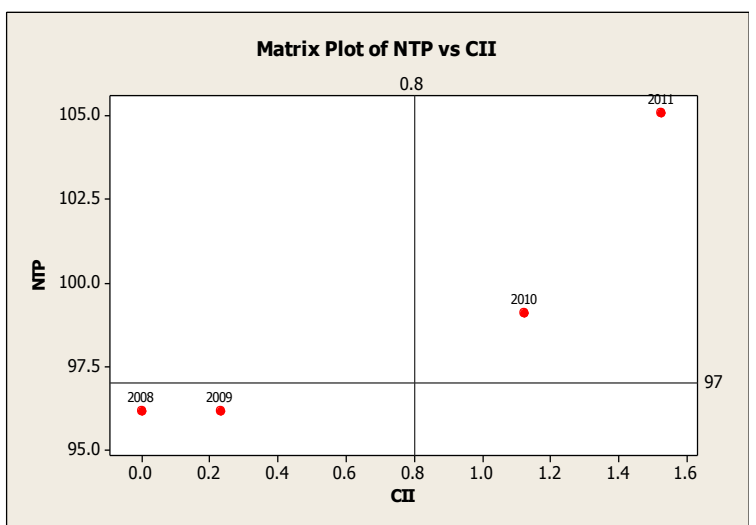

Gambar 8 Pola Hubungan Nilai Tukar Petani (NTP) vs Indeks Ketidakstabilan

Gambar 9 mengilustrasikan pola hubungan antara produksi pertanian dengan indeks ketidakstabilan coppock (CII). Ditunjukkan pula pada gambar tersebut bahwa hubungan antara produksi dan CII ialah kurva U-terbalik dimana peningkatan produksi cenderung meningkatan indeks ketidakstabilan pada struktur ekonomi perikanan di Jawa Barat. Artinya ialah harus ada faktor lain selain peningkatan jumlah produksi 
perikanan agar dapat meningkatkan kestabilan struktur ekonomi perikanan di Jawa Barat.

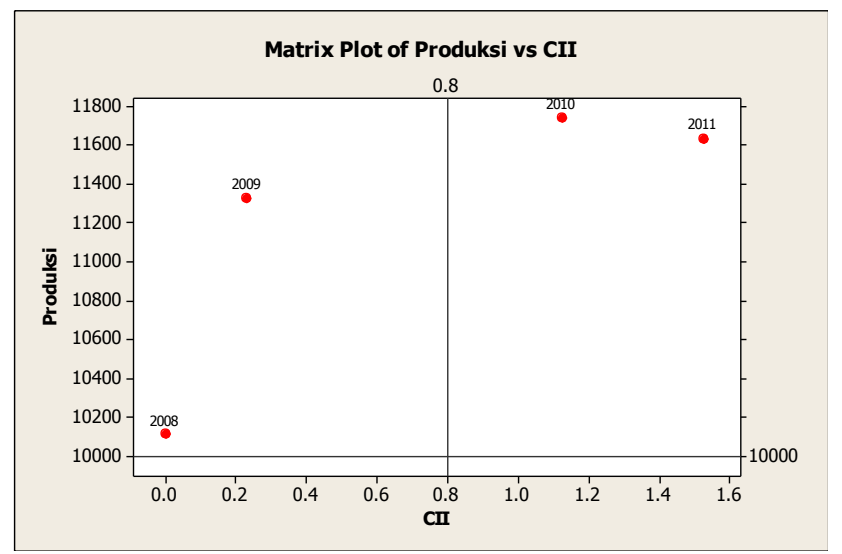

\section{Gambar 9 Pola Hubungan Produksi vs Indeks Ketidakstabilan Coppock (CII)}

Tabel 4 mengilustrasikan hubungan antara Indeks ketidakstabilan (CII) dengan faktorfaktor lainnya yakni jumlah petani dan produksi. Dari hasil analisis diketahui bahwa Indeks ketidakstabilan (CII) berkorelasi positif $(0,92)$ dengan NTP, artinya ada hubungan antara peningkatan ketidakstabilan NTP dengan nilai NTP sebesar 91,7\%. Di sisi lain indeks CII berkorelasi negatif $(-0,33)$ dengan jumlah petani yang artinya, peningkatan jumlah petani cenderung akan menurunkan indeks ketidakstabilan sebesar 33\%. Sedangkan dari sisi produksi, indeks CII berkorelasi positif $(0,80)$ yang artinya peningkatan produksi pertanian cenderung akan meningkatan ketidakstabilan NTP sebesar 79,5\%.

Tabel 4 Hubungan antara Indeks Ketidakstabilan (CII) dengan variabel input dan output di sektor pertanian dan perikanan di Jawa Barat

\begin{tabular}{|c|c|c|c|c|}
\hline \multicolumn{5}{|c|}{ Sektor Pertanian } \\
\hline Variabel & CII & NTP & Jml Petani & Produksi \\
\hline CII & - & 0,92 & $-0,33$ & 0,80 \\
\hline NTP & & - & $-0,67$ & 0,58 \\
\hline Jml Petani & & & - & 0,20 \\
\hline Produksi & & & & - \\
\hline \multicolumn{5}{|c|}{ Sektor Perikanan } \\
\hline Variabel & CII & NTN & Jml Nelayan & Produksi Ikan \\
\hline CII-Perikanan & - & $-0,92$ & - & $-0,27$ \\
\hline NTN & - & - & - & - \\
\hline Jml Nelayan & -0.874 & 0,99 & $-0,87$ & 0,67 \\
\hline Produksi Ikan & - & - & - & \\
\hline
\end{tabular}

NTP juga berkorelasi negatif $(-0,67)$ dengan jumlah petani yang artinya semakin tinggi jumlah petani cenderung menurunkan nilai NTP sebesar $67 \%$. Namun demikian, nilai NTP berkorelasi positif $(0,58)$ dengan produksi yang artinya peningkatan produksi padi sebesar satu satuan akan cenderung meningkatkan nilai NTP sebesar 57,6\%.

Hubungan antara NTN dengan indeks ketidakstabilan (CII) dengan jumlah nelayan dan produksi ikan ditunjukkan pada Tabel 3. Tabel 3 menunjukkan jumlah nelayan memiliki korelasi yang positif $(0,99)$ dengan NTN. Artinya, ada hubungan linier antara jumlah nelayan dengan NTN sebesar 99,5\%. Di sisi lain, variabel jumlah nelayan dan NTN memiliki korelasi negatif dengan indeks CII masing-masing sebesar -0,92 dan -0,87. Artinya, peningkatan jumlah nelayan dan NTN cenderung akan menurunkan ketidakstabilan sebesar 87,4 \% dan 91,9\%. 


\section{SIMPULAN DAN SARAN}

\section{Simpulan}

1. Hasil analisis Data Envelopment Analysis (DEA) menunjukkan bahwa selama periode 2001 sampai 2012 sektor pertanian cenderung mengalami kinerja membaik. Sementara di sektor perikanan cenderung berfluktuasi. Kinerja output pertanian dapat diperbaiki sebesar 8,75\% dari kondisi eksisting. Sementara kinerja produksi perikanan dapat ditingkatkan sampai dengan $9,5 \%$.

2. Peningkatan nilai tukar petani (NTP) dan nilai tukar nelayan (NTN) berimplikasi pada meningkatnya indeks ketidakstabilan. Interaksi antara indeks ketidakstabilan dengan input dan output (tenaga kerja, NTP dan NTN) menunjukkan adanya dinamika kebijakan terhadap input dan output di sektor perikanan dan pertanian.

3. Pada sektor pertanian, NTP dan produksi berkorelasi positif terhadap CII. Artinya, semakin tinggi NTP dan produksi cenderung tidak stabil pada aspek kesejahteraan petani. Pada sektor perikanan terjadi sebaliknya, kenaikan NTN dan produksi cenderung menstabilkan kesejahteraan. Hal ini mungkin disebabkan oleh sifat perikanan tangkap yang lebih berburu daripada dibudidayakan.

\section{Saran}

1. Intervensi kebijakan terhadap sarana produksi, dan kebijakan harga pertanian dan perikanan dapat membantu meningkatkan kinerja produksi di kedua sektor tersebut.

2. Redistribusi tenaga pertanian dapat dilakukan dari fokus ke hulu (sebagai petani) menjadi ke hilir (industri pertanian dan perikanan). Sehingga diperlukan intervensi kebijakan berupa insentif fiskal untuk melakukan hilirisasi tenaga kerja tersebut.

3. Efisiensi sarana produksi perikanan harus dilakukan dengan cara mengurangi armada di bawah 7 GT dan meningkatkan kekuatan armada di atas 7 GT.

4. Untuk menurunkan indeks ketidakstabilan kesejahteraan (Coppock Instability Index) dapat ditempuh melalui kebijakan-kebijakan mikro seperti: bantuan sarana produksi yang sifatnya gradual dan selektif.

5. Sektor-sektor berbasis sumberdaya alam ialah sektor yang sangat dipengaruhi oleh external shock variabel.

6. Pemerintah perlu menciptakan suatu mekanisme agar jumlah produksi pertanian tidak fluktuatif.

\section{DAFTAR PUSTAKA}

Auty RM. 1993. Sustaining Development in Mineral Economies: The Resource Curse Thesis. Routledge, London.

BPS. 2012. Jawa Barat Dalam Angka. Badan Pusat Statistik Provinsi Jawa Barat, Bandung.

Charnes, A, W.W. Cooper, and E. Rhodes. 1978. Measuring the efficiency of decision making units. European Journal of Operational Research 2, pp 429-444. Coppock, J.D. (1962). International Economic Instability. McGraw-Hill, New York.

Fauzi A. 2007. Economic of Nature Non Convexity. Reorientasi pembangunan ekonomi sumber daya alam dan implikasinya bagi Indonesia, Orasi Guru Besar Fakultas Ekonomi dan Manajemen IPB. 10 November 2007.

Fauzi A, and Z. Anna. 2011. Growth and Instability of Small Pelagic Fisheries of the North Coats of Java, Indonesia. Lesson learned for Fisheries Policy. China-USA Business Review Vol.11, No.6 pp. 739-748.

Karjogi R, B. Namaker, and L.B. Kunnal. 2009. Growth in Area and Production of Eucalyptus in Karnataka. Mysore J. Agric.Sci. Vol.43, No.4 pp. 641-645. 
Reddy AA. 2009. Growth and Instability in Chickpea Production in India: A State Level Analysis. Retrieved from http://ssrn.com/abstract=1499577.

Shah D. 2007. Managing Fisheries Development in Maharashtra. MPRA Paper No. 3924. Retrieved from http://mpra.ub.uni-munchen.de/3924.

Wasim MP. 2007. Issues, Growth and Instability of Inland Fish Production in Sindh (Pakistan): Spatial Temporal Analysis. Pakistan Economic and Social Review Vol.45 No.2 pp. 203-230. 